\title{
Pharmacognostical Screening and Radical Scavenging Activity of Nicker Bean seed
}

\author{
Ajay Dewangan*, Harish Pandey, Neelesh Chaubey \& Rajendra Chouksey \\ College of Pharmacy, SSSUTMS, Sehore, India
}

DOI: $10.36348 /$ sijtcm.2020.v03i02.001

| Received: 19.01.2020 | Accepted: 27.01.2020 | Published: 08.02.2020

*Corresponding author: Ajay Dewangan

Abstract

The utilization of botanicals has gained more significance because of its natural origin and high therapeutic significance. The plant Nicker Bean botanical known as Caesalpinia bonducella has been used in diverse system of traditional medication for the treatment of diseases and ailments of human beings. The Plant has been reported as anti-asthmatic, antidiabetic, anti-inflammatory, anti-oxidant, anti-bacterial, anti-filarial, anti-tumor, immunomodulatory, hypoglycemic, activity. The work deals with preliminary Pharmacognostical studies of Caesalpinia bonducella seed, further seed extracts (ethanolic and aqueous) were evaluated for radical scavenging activity.

Keywords: Caesalpinia bonducella, Physiochemical parameters, phytochemical screening \& radical scavenging.

Copyright @ 2020: This is an open-access article distributed under the terms of the Creative Commons Attribution license which permits unrestricted use, distribution, and reproduction in any medium for non-commercial use (NonCommercial, or CC-BY-NC) provided the original author and source are credited.

\section{INTRODUCTION}

The therapeutic worth of many indigenous plants, for various diseases has been described by traditional herbal medicinal practitioners. Natural products are the source of synthetic and traditional herbal medicine [1]. Ancient Indian literatures incorporate a extremely broad definition of medicinal plants to be potential sources of medicinal substances [2]. More than 500 species of Caesalpinia has been identified has medicinal benefits based on their pharmacological activity. One of the medicinal plants from this genus is Caesalpinia bonducella Linn. (C. bonducella) an Indian herb belonging to Family Caesalpiniaceae[3]. The name of the species "Bonducella" is derived from the Arabic word "Bonduce" meaning a "little ball" which indicated the globular shape of the seed [4]. The reactive oxygen species (ROS) stir up superoxide anionic radical $\left(\mathrm{O}^{2-}\right)$, hydrogen peroxide $\left(\mathrm{H}_{2} \mathrm{O}_{2}\right)$ and hydroxyl radicals $(\mathrm{OH})$ are implicated in oxidative damage to various cellular macromolecules. Increasing number of confirmation suggested that oxidative stress induced biochemical changes are crucial etiological factors in several chronic human diseases such as diabetes mellitus, cancer, atherosclerosis, arthritis, inflammation and neurodegenerative diseases. There are many synthetic antioxidants such as butylated hydroxyanisol (BHA) and butylated hydroxytoluene (BHT) are available which are renounced unsafe. Therefore, in recent year's considerable attention has been directed to recognize the natural antioxidants (plant derived) that may be used for human consumption ${ }^{5}$.In the present investigation we have attempted to investigate preliminary phytochemical screening along with antioxidant potential in ethanolic and aqueous extract of seed of Caesalpinia bonducella.

\section{MATERIALS AND METHODS \\ Collection \& Authentication}

Herb was collected from Moolchand and phoolchand shop, jummerati, bhopal (M.P). The plant was collected in the month of August- September 2019 $\&$ authenicated. Seeds were separated and were made completely clean and dust free.

\section{Drying and Size Reduction of Plant Material}

The plant material was dried under shade. It was pulverized to coarse powder with the help of mixer grinder. The coarse powder was passed through sieve No.20 to maintain uniformity and packed into airtight container and stored in cool and dry place. This material was used for the further study.

\section{Preparation of Crude Extract}

500 gram of powdered plant material was extracted using a Soxhlet apparatus with $500 \mathrm{ml} 90 \%$ ethanol and 500 gram with distilled water at $60-70^{\circ} \mathrm{C}$ for 35 complete cycles. The extracts were dried at 30 $40^{\circ} \mathrm{C}$. 


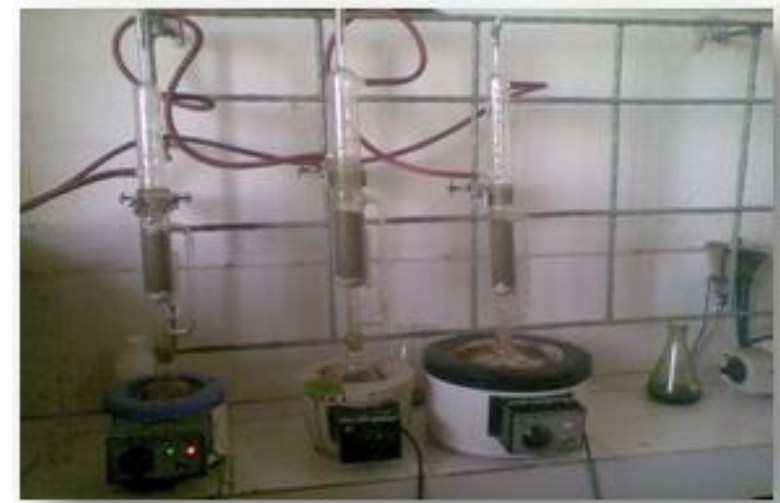

Fig-1: Extraction process

\section{PHARMACOGNOSTICAL SCREENING Organoleptic evaluation}

Various outer morphological characteristics like color, shape, size taste etc. were identified.

\section{Screening of seed powder (Physiochemical analysis) [6-8] \\ Loss on Drying}

$10 \mathrm{gm}$ of the powdered drug was weighed in a tarred petridish. It was dried at $105^{\circ} \mathrm{C}$ for 1 hour in hot air oven and then reweighed. Loss on drying was determined by calculating the initial and final weight.

\section{Total Ash value}

About $5 \mathrm{gm}$ accurately weighed powdered drug was incinerated in a silica dish at a temperature not exceeding $450^{\circ} \mathrm{C}$ until free from carbon in muffle furnace. It was then cooled and weighed. The $\% \mathrm{w} / \mathrm{w}$ of ash with reference to the air-dried drug was calculated.

\section{Acid insoluble ash value}

1 gram ash was boiled for 5 minute with $25 \mathrm{ml}$ hydrochloric acid by covering the crucible with a watch-glass on water bath then cooled. The watch-glass was rinsed with $5 \mathrm{ml}$ of hydrochloric acid and this liquid was added in to the crucible. Then the content was filtered on a previously weighed filter paper and filtrate was dried and weighed. Acid insoluble ash value was determined by calculating the $\%$ content remaining after deducting the weight of filter paper.

\section{Water soluble ash value}

1 gram ash was boiled for 5 minute with $25 \mathrm{ml}$ distilled water by covering the crucible with a watchglass on water bath then cooled. The watch-glass was rinsed with $5 \mathrm{ml}$ of distilled water and this liquid was added in to the crucible. The $\%$ of remaining content was deducted from initial $\%$ of ash taken (i.e. 100\%) to determine the water soluble ash value.

\section{Foaming Index}

$1 \mathrm{gm}$ coarse powder was weighted and transferred to a $500 \mathrm{ml}$ conical flask containing $100 \mathrm{ml}$ of water. It was maintained at moderate boiling for 30 minute on water bath. It was cool and filtered in to a $100 \mathrm{ml}$ volumetric flask. Volume was diluted by adding sufficient amount of water. The decoction was poured in test tube, and then shaken in a lengthwise motion for 15 seconds. They were allowed stand for 15 minutes and the height of foam was measured to determine the foaming index.

\section{Screening of crude extracts (Qualitative Phyotochemical Analysis)}

The crude extracts obtained by solvent extraction were subjected to various qualitative tests to detect the presence of common chemical constituents as:

\section{Tests for Alkaloids \\ Dragendorff's test}

To the $1 \mathrm{ml}$ of extract, add $1 \mathrm{ml}$ of Dragendorff's reagent (potassium bismuth iodide solution). An orange-red precipitate indicates the presence of alkaloids.

\section{Mayer's test}

To the $1 \mathrm{ml}$ of extract, add $1 \mathrm{ml}$ of Mayer's reagent (Potassium mercuric iodide solution). Whitish yellow or cream coloured precipitate indicates the presence of alkaloids

\section{Tests for Glycosides Legal's test}

Dissolve the extract in pyridine and add sodium nitroprusside solution to make it alkaline. No formation of pink to red colour shows absence of glycosides.

\section{Baljet's test}

To $1 \mathrm{ml}$ of the test extract, add $1 \mathrm{ml}$ of sodium picrate solution and the yellow to orange color reveals the presence of glycosides.

\section{Tests for carbohydrate Benedict's test}

To $5 \mathrm{ml}$ of Benedict's reagent, add $1 \mathrm{ml}$ of extract solution and boil for 2 minutes and cool. Formation of red precipitate shows the presence of sugars.

\section{Molisch's test}

A small fraction from the respective extracts was taken in ethanol separately and a few drops of $20 \%$ $\mathrm{w} / \mathrm{v}$ solution of $\alpha$-napthol in ethanol $(90 \%)$ were added to it. After shaking well, about $1 \mathrm{ml}$ of concentrated sulphuric acid was allowed to flow carefully by the side of the test tube. A reddish violet ring at the junction of the two layers indicated the presence of carbohydrates.

\section{Tests for steroids Salkowski test}

The extract was dissolved in chloroform and equal volume of conc. $\mathrm{H}_{2} \mathrm{SO} 4$ was added. Formation of bluish red to cherry color in chloroform layer and green 
fluorescence in the acid layer represents the steroidal components in the tested extract.

\section{Liebermann-Burchard test}

A small portion from each extract was taken with about $1 \mathrm{ml}$ of acetic anhydride and dissolved by warming. The contents were cooled and a few drops of concentrated sulphuric acid were added in each case by the sides of the test tube. Appearance of blue colour indicated the presence of sterols.

\section{Test for Proteins \\ Biuret test}

Add $1 \mathrm{ml}$ of $40 \%$ sodium hydroxide solution and 2 drops of $1 \% \mathrm{CuSO} 4$ solution till a blue color is produced, and then add to the $1 \mathrm{ml}$ of the extract. Formation of pinkish or purple violet color indicates the presence of proteins.

\section{Tests for Saponins}

A little fraction from the various extracts were boiled with about $1 \mathrm{ml}$ of distilled water and shaken. Appearance of a characteristic foam formation indicated the presence of Saponins. Aqueous and alcoholic extracts were tested directly.

A little fraction from various extracts was taken with about $2 \mathrm{ml}$ of distilled water. A small quantity of sodium carbonate was added to each and shaken. The characteristic foam formation indicated the presence of Saponins. Aqueous and alcoholic extract were tested directly.

\section{Tests for Tannins}

A small fraction of the residue from each extract was dissolved in about $2 \mathrm{ml}$ of distilled water separately and filtered. The filtrate was tested with the Ferric chloride solution. Appearance of a blue to bluish green or bluish-black colour indicated the presence of tannins

\section{Tests for Flavonoids \\ Shinoda test}

To the test solution add few magnesium turnings and concentrated hydrochloric acid dropwise, pink scarlet, crimson red or occasionally green to blue colour appears after few minutes.

\section{Alkaline reagent test}

To the test solution add few drops of sodium hydroxide solution, intense yellow color is formed which turns to colorless on addition of few drops of dilute acid indicate presence of Flavonoids.

\section{ANTIOXIDANT ACTIVITY DPPH Radical Scavenging Activity}

Ascorbic acid and $\mathrm{EtOH} *$ Aqueous extract were weighed ( $25 \mathrm{mg}$ each) and dissolved in $250 \mathrm{ml}$ of methanol to get $500 \mu \mathrm{g} / \mathrm{ml}$ stock solutions separately. Lower concentrations of ascorbic acid and extracts (2,
$4,6,8,10 \mu \mathrm{g} / \mathrm{ml}$ and $2,4,6,8,10 \mu \mathrm{g} / \mathrm{ml}$ respectively) were prepared by serially diluting stock solutions. The stable DPPH radical was used for determination of free radical-scavenging activity of the extracts. The $0.1 \mathrm{mM}$ solution of DPPH in methanol (22.2 mg in $1000 \mathrm{ml})$ was freshly prepared. Different concentrations of extracts were added at an equal volume $(2 \mathrm{ml})$ to methanolic solution of DPPH. After $30 \mathrm{~min}$ at room temperature, the absorbance was recorded at $517 \mathrm{~nm}$. $\mathrm{IC}_{50}$ values denote the concentration of sample, which is required to scavenge $50 \%$ of DPPH free radicals. Radical scavenging activity was calculated by the following formula [9].

$\%$ Radical Scavenging Activity = Acontrol- Asample /Acontrol * 100

Where, Acontrol = Absorbance of control Asample = Absorbance of sample

The inhibition curve was plotted for duplicate experiments and represented as $\%$ of mean

Inhibition \pm standard deviation

$\%$ Radical Scavenging Activity $=\mathrm{A}_{\text {control }} \mathrm{A}_{\text {sample }} / \mathrm{A}_{\text {control }}$ $* 100$

Where, $\mathrm{A}_{\text {control }}=$ Absorbance of control $\mathrm{A}_{\text {sample }}=$ Absorbance of sample

The inhibition curve was plotted for duplicate experiments and represented as $\%$ of mean

Inhibition \pm standard deviation

\section{RESULT AND DISCUSSION}

The remedial properties of medicinal plants are possibly due to the presence of various secondary metabolites such as alkaloids, flavonoids, glycosides, phenols, saponins, sterols etc. The macroscopic characteristics of $C$. Bonducella seed was tabulated in table 1 . The phytochemical parameters were tabulated in table 2. The successive extraction seed of $C$. Bonducella were carried out in ethanol \& water. The result was tabulated in table 3 . The successive extraction was carried out by hot percolation method and \% yield was determined (table 4). The reveals that ethanolic extract showed high $\%$ as compared with aqueous extract. The preliminary phytochemical tests revealed the presences of flavonoids, saponins \& glycosides in both the extracts. (Table 5).Thus, the preliminary screening tests may be helpful in the detection of the bioactive principles and consequently may lead to the drug discovery and development. Antioxidant activities of both the extracts were carried out by DPPH by using ascorbic acid as standard. DPPH is a purple-coloured stable radical of organic nitrogen with a maximum absorbance at $517 \mathrm{~nm}$ and it is widely used to study radical scavenging activities of extracts and pure compounds. When the odd electron becomes paired off in the presence of a free radical scavenger to form 
hydrazine, the absorption reduces and the DPPH solution is decolourised from deep violet to light yellow. The degree of reduction in absorbance measurement is indicative of the radical scavenging (antioxidant) power of the extract. $\mathrm{IC}_{50}$ (concentration required to obtain a $50 \%$ antioxidant capacity or is the concentration of substrate that brings about $50 \%$ loss of the DPPH) is typically employed to express the antioxidant activity and to compare the antioxidant capacity of various samples $[2,4]$. In the present study, the $\mathrm{IC}_{50}$ values of ethanolic and aqueous extract were found to be 19.1 and $21.46 \mu \mathrm{g} / \mathrm{ml}$. The results were tabulated in table 6 and the \% inhibitions vs. concentration graph were showed in fig. $2,3 \& 4$.

\section{CONCLUSION}

The present study deals with macroscopic, phytochemical analysis and antioxidant activity of $\mathrm{C}$. Bonducella seed. These studied will provide referentially information for correct identification and for standardization. The preliminary phytochemical screening of aqueous \& ethanolic extracts showed presence of flavonoid in both the extracts. Free radical creation in animal cells can either be accidental or deliberate. With the increasing acceptance of free radicals as common place and important biochemical intermediates, they have been implicated in a large number of human diseases. The scavenging activity of flavonoids present in aqueous and ethanolic extract had been determined by DPPH.
Table-1: Organoleptic Seed characteristic

\begin{tabular}{|l|l|l|}
\hline S.No. & Characteristics & \multicolumn{1}{|c|}{ Observation } \\
\hline 1. & Colour & $\begin{array}{l}\text { The seed color was dark } \\
\text { Green. }\end{array}$ \\
\hline 2. & Odor & Characteristic \\
\hline 3. & Taste & Acrid \\
\hline 4. & Size & $\begin{array}{l}2-2.5 \mathrm{~cm} \text { length, } 0.5-1 \mathrm{~cm} \\
\text { width }\end{array}$ \\
\hline 5. & Texture & Soft \\
\hline 6. & Fracture & Tough. \\
\hline
\end{tabular}

Table-2: Physiochemical analysis

\begin{tabular}{|c|c|c|}
\hline S.No. & Parameters & Observations \\
\hline 1 & Loss on drying & $0.1 \%$ \\
\hline 2 & Foaming index & Less than $20 \%$ \\
\hline 3 & Total Ash value & $2.95 \%$ \\
\hline 4 & Acid insoluble ash value & $1.27 \%$ \\
\hline 5 & Water soluble ash value & $1.19 \%$ \\
\hline
\end{tabular}

Table-3: Extractive values of Ceasalpinia Bonducella

\begin{tabular}{|c|c|c|}
\hline Plant & Ethanol & Water \\
\hline Ceasalpinia Bonducella & $0.89 \%$ & $0.7 \%$ \\
\hline
\end{tabular}

Table-4: \% yields of Successive Solvent extracts of Ceasalpinia Bonducella in following solvents

\begin{tabular}{|c|c|c|}
\hline S. NO. & Extracts & Percentage yield \\
\hline $\mathbf{1}$ & Ethanolic & $1.3 \%$ \\
\hline $\mathbf{2}$ & Aqueous & $1.8 \%$ \\
\hline
\end{tabular}

Table-5: Phytochemicals Screening of Ceasalpinia Bonducella seeds.

\begin{tabular}{|l|l|c|c|c|}
\hline S.No. & Phytochemicals & Test & Ethanolic extract & Aqueous extract \\
\hline 1 & Alkaloids & Mayer's test, Dragendorff's test & - & - \\
\hline 2 & Tannins & Ferric chloride test & - & + \\
\hline 3 & Flavonoids & Shinoda's Test & + & + \\
\hline 4 & Glycosides & Legal's test ,Baljet's test & + & + \\
\hline 5 & Carbohydrates & Benedict's test & - & - \\
\hline 6 & Amino acid & Biuret test & - & + \\
\hline 7 & Fixed oil \& Fats & Spot test & - & + \\
\hline 8 & Steroid & Salkowski test & + & + \\
\hline 9 & Saponins & By shaking the extract in test tube & + \\
\hline
\end{tabular}
(+ Present, - Absent)

Table-6: 50\% inhibition ( $\mathrm{IC}_{50}$ ) of Aqueous \& ethanolic extract of $C$. Bonducella seeds by DPPH method

\begin{tabular}{|c|c|c|}
\hline S.No & Sample & $\mathbf{I C}_{\mathbf{5 0}}(\boldsymbol{\mu g} / \mathbf{m l})$ \\
\hline 1. & Ascorbic acid & 3.17 \\
\hline 2. & Aqeous extract & 19.1 \\
\hline 3. & Ethanolic extract & 21.46 \\
\hline
\end{tabular}

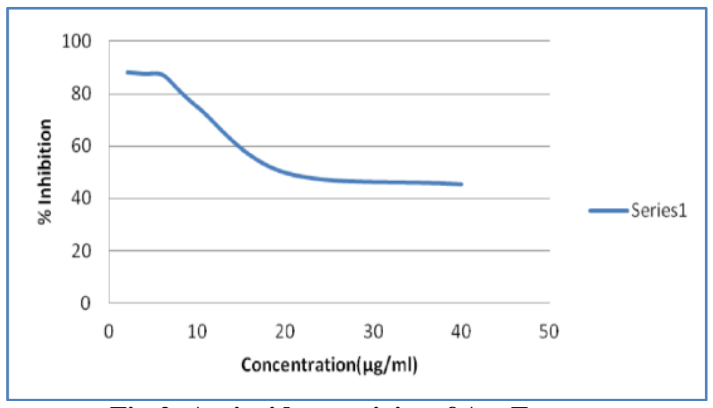

Fig-2: Antioxidant activity of Aq. Extract 


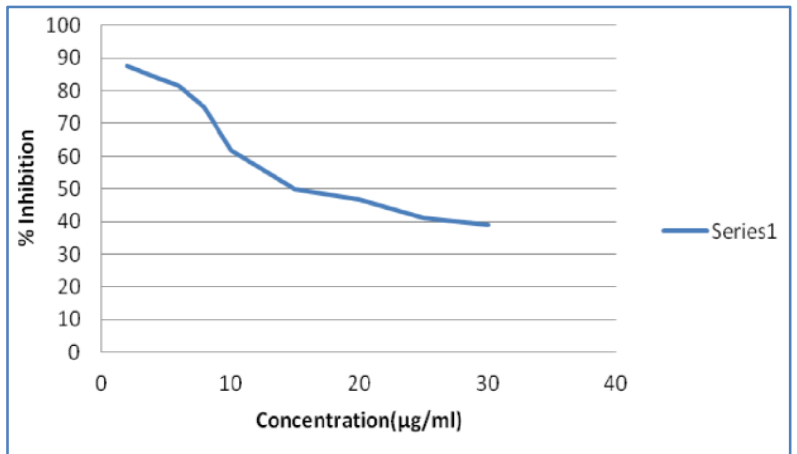

Fig-3: Antioxidant activity of ethanolic extract

\section{REFERENCE}

1. Himesh, S. O. N. I., Singhai, A. K., \& Sarvesh, S. (2012). Quantification of ascorbic acid in leaves of Annona squamosa. International Journal of Pharmacy and Pharaceutical Sciences. ISSN. 0975-1491 Vol, 4, 1-6.

2. Soni, H., Mishra, K., Sharma, S., \& Singhai, A. K. (2012). Characterization of Azadirachtin from ethanolic extract of leaves of Azadirachta indica. Journal of Pharmacy Research, 5(1), 199201.

3. Sembiring EN, Elya B, Sauriasari R. Phytochemical screening, total flavonoid and total phenolic content and antioxidant activity of different parts of Caesalpinia bonduc (L.) Roxb. Pharmacognosy journal. 2018;10(1).

4. Handa, S. S., \& Kaul, M. K. (1996). Supplement to cultivation and utilization of medicinal plants.

5. Soni, H., Nayak, G., Mishra, K., Singhai, A. K., \& Pathak, A. K. (2010). Evaluation of Phyto Pharmaceutical and Antioxidant Potential of Methanolic Extract of Peel of Punica granatum. Research Journal of Pharmacy and Technology, 3(4), 1170-1174.

6. Mukharjee, P.K. (2002). Quality control of herbal drugs- an approach to evaluation of botanicals $31^{\text {st }}$ edition. New Delhi, Business Horizons Pharmaceuticals. Publications, 183-197.

7. Khandelwal, K.R. (1996). Practical Pharmacognosy. $\quad 3^{\text {rd }}$ edition. Pune: Nirali Prakashan, 165.

8. Semwal, P.(2019). Pharmacognostical \& TLC Fingerprinting of Kiratatikta, EAS Journal of Pharmacy and Pharmacology, 1(6), 170-177.

9. Himesh, S. O. N. I., Nanda, S. A. H. U., Singhai, A. K., \& Jitender, M. A. L. I. K. (2012). Radical scavenging activities and natural indicator activity of aqueous and ethanolic extract of Rosa damascena. Int J Pharm Pharm Sci, 4(SUPPL 5), 581-6. 